\title{
Animals Who Think and Love: Law, Identification and the Moral Psychology of Guilt
}

\author{
Alan Norrie $^{1}$ (D) \\ Published online: 2 November 2018 \\ (c) The Author(s) 2018
}

\begin{abstract}
How does the human animal who thinks and loves relate to criminal justice? This essay takes up the idea of a moral psychology of guilt promoted by Bernard Williams and Herbert Morris. Against modern liberal society's 'peculiar' legal morality of voluntary responsibility (Williams), it pursues Morris's ethical account of guilt as involving atonement and identification with others. Thinking of guilt in line with Morris, and linking it with the idea of moral psychology, takes the essay to Freud's metapsychology in Civilization and Its Discontents. Two conflicting routes to guilt are noted in Freud, one involving internalisation of external anger to suppress destructive instincts, the other loving identification with others in the process of selfformation. This second route is developed through the psychoanalytic thought of Hans Loewald and Jonathan Lear. Following Loewald, the moral psychology of selfformation makes loving identification with others the root of responsibility, guilt and atonement. Following Lear, the moral psychology of guilt developed on these lines renders psychoanalysis part of a broadly understood philosophical project following Aristotelian and Socratic principles. Underlying Morris's account of guilt is the possibility of 'prospective identification', understood as the moral and psychological ground of guilt and reconciliation. This is the rational core of criminal justice, which maintains an uneasy relationship with law's 'peculiar' morality.
\end{abstract}

Keywords Criminal justice $\cdot$ Guilt $\cdot$ Moral psychology $\cdot$ Identification $\cdot$ Love $\cdot$ Freud

Nothing of him that doth fade,

But doth suffer a sea-change

Into something rich and strange.

Shakespeare, The Tempest

In the introduction to a recent set of essays, Jeffrie Murphy notes he started to question his commitment to retributive philosophy in the light of the thought, amongst others, of

Alan Norrie

A.W.Norrie@warwick.ac.uk

1 Warwick Law School, University of Warwick, Coventry, UK 
Freud (Murphy 2012, xii). Murphy follows in the footsteps of others disenchanted with philosophical debate around punishment. His essay on the ethical concerns animating guilt and shame pursues a critical line that takes in the work of earlier objectors like Bernard Williams and Herbert Morris, behind whom there also lurks Freud's metapsychology (Murphy 2012, ch. 5). But how exactly does psychoanalytic thinking relate to the philosophy of punishment, and what exactly does it say about issues of guilt, blame and responsibility? This essay considers both of these questions. As regards the first, it considers the relationship between metapsychology and philosophy, arguing that these should be seen as two parts of one larger, philosophical, endeavour. As for the second, it argues for a different direction in Freud's theory, and how it regards issues of guilt and responsibility, than the standard approach.

My focus is Freud's understanding of guilt in his book, Civilization and Its Discontents, where the obvious reading is not the most helpful, but where a different reading can be developed to illuminate the moral concerns of thinkers like Murphy, Williams and Morris. The problem with the obvious reading is briefly identified by Murphy. We may agree 'that the development of a moral sense or conscience (a super-ego)... involves the internalization of parental commands perceived as authoritative' (Murphy 2012 , 96), but then we should note that a causal reading of guilt cannot account for the moral person thinking critically, for example, by challenging parental or other authority figures. This is a fair criticism of Freud's account as it is normally, and reasonably, taken on the face of his text. But there is a way of constructing the metapsychology of guilt that is completely in line with Freud, yet pursues a more promising strand in a complex and conflicted oeuvre. Guilt can be seen as based on responsibility and a wish to atone for wrongdoing that is not derived from internalised fear of external authority figures. Rather, it comes from the way humans develop as rational, autonomous, loving beings in relation with each other, as animals who think and love.

Developing this argument, I revisit Morris's idea of a moral psychology of guilt alongside Williams's critique of liberal morality. Williams, also arguing for a moral psychology, represented an important bridgehead to a better understanding of the relation between legal responsibility and moral guilt, while Morris developed a substantive way forward. The argument I will make concerns an account of identification, which is crucial both to psychoanalysis and understanding moral guilt. It is the explicit key to one of Morris's arguments, and I will develop it in the direction of Freud in a specific way, following the path-breaking work of Jonathan Lear and his psychoanalytic mentor, Hans Loewald. This provides the basis for a more sophisticated ethical account in line with Morris's and Williams's concerns. It also, in Lear's work, reveals the internal connections between metapsychology and philosophy, promoting a synthetic understanding of philosophy along Aristotelian lines that includes metapsychology.

\section{Two Critiques of Modern Guilt}

A truthful ethical life is, and always has been, one that can include our best understanding of our psychological life, and we know that such an understanding is compatible with naturalistic explanation (Williams 1995, 19-20). 
In this section, I outline what I call Williams's bridgehead for two critiques of the modern idea of guilt. I start with his account of modern moral philosophy as a 'peculiar' institution, before identifying the political and ethical critiques of modern morality as it affects the understanding of guilt as a question of voluntary action.

\subsection{Engaging the 'Peculiar' Institution}

The bridgehead that I find in Williams takes critique in two directions, both of which are linked to the nature of modern morality, which he described as a 'peculiar' institution (Williams 2011, ch. 10). What I wish to bring out is the way that his account of morality links with his understanding of law, and how its limits, its peculiarities, reflect its connection to legal institutions. These limits at the same time point to ethical possibilities that lie beyond morality in its 'peculiar' form, possibilities that he summed up by invoking the idea, like Morris, of a naturalistic moral psychology (Morris 1976). This should reflect more broadly and more truly on the nature of moral experience than does what we might call 'actually existing morality', morality in its 'peculiar' form, as endorsed in modern liberal political and legal thought.

One focus of Williams's argument was concepts of blame, guilt and responsibility, all of which reflected aspects of morality's 'peculiar' modern form, and the critical bridgehead goes in two ways. The first is to the political critique of the modern moral understanding of these terms. Blame, guilt and responsibility are moral terms that are systematically limited and impoverished by their connection to modern institutional forms of a political and legal nature, linked to the liberal state. The second is an ethical critique going to the deeper moral psychology of these same terms, which Williams glimpsed, but did not himself really pursue. Important here was his emphasis on going to theorists of morality beyond the mainstream, but who he thought, precisely because they were beyond the mainstream, had something different to offer. Amongst those that Williams noted as providing a better account of morality was Freud, though he did not elaborate. ${ }^{1}$

Pursuing this second critique here, I take up Morris's account of guilt, which provides a deeper, substantive, account of guilt, one that wrestles with how Williams's 'peculiar' institution sees it, and finds a way beyond it. Morris had read Freud and was wont to discuss him. Though he does not credit his account of identification to reading Freud, there is a clear connection in how he expresses it. Developing Morris's concept of identification in a way that makes the link clear, via Lear's philosophical understanding of Freud, gives us a fresh development of the moral grammar of blame and guilt utilised in modern morality's actually existing form. ${ }^{2}$ I begin with the first, political, critique, which situates the problem that the second, ethical, critique - the main focus of this essay — then engages.

\footnotetext{
1 On the significance of Williams's opening of philosophy both to a limited Nietzschean critique and to psychoanalysis, see Lear (2003, 2004).

2 Of comparative interest here is another, metaphysical, critique of modern morality based on an ethics of love offered by the young Hegel, before he himself succumbed to the modern form in his mature work: see Norrie (2018a).
} 


\subsection{A Political Critique: Against Conflation}

Writing of modern morality as a 'peculiar' institution in Ethics and the Limits of Philosophy (2011), Williams noted that it served the function of rendering modern society workable. Focusing on the nature of obligation, he noted that it secured reliability in social matters, for people could reasonably expect others to behave in certain ways. However, it bought social functionality at a price. Williams saw blame as central to crime and punishment, but as involving the fiction that people were free to act otherwise than they did. Agents were treated as though relevant ethical considerations established by state and law were reasons on which they acted. The system had the function of continuously recruiting citizens into the fiction of a universal, deliberative community, and this was an achievement of the morality system. He questioned, however, whether-since it was a fiction-the system could survive a clear understanding of how it worked.

In its place, Williams offered an ethical approach that could more openly and honestly reflect the true nature of human ethical being. What he argued for was

a reflective and nonmythical understanding of our ethical practices. It is certain that the practices of blame, and more generally the style of people's negative ethical reactions to others, will change. The morality system, in my view, can no longer help them to do so in a desirable way (Williams 2011, 215).

Williams added that the key, and problematic, concept was that of 'the voluntary'. Linking a person's acts unproblematically to her character, he argued that the system's focus did not ask about the freedom to have chosen another character, so that the blame system narrowly focused on the conditions of the particular act. It was only able to do this because it did not operate alone, being linked to other practices of encouragement and discouragement to keep to the law, but this additional institutional support for moral concepts of the voluntary was ignored within the moral system itself. There is a 'pressure within [the system] to require a voluntariness that will be total and will cut through character and psychological or social determination', allocating blame on no more or less than what is claimed to be 'the ultimately fair basis of the agent's own contribution' (Williams 2011, 216). Williams does not see this as ultimately fair at all, for it ignores the moral information that would otherwise ground an ethics that could address how and why people act, and how they might be morally persuaded to behave in ways non-violative of others. Most know that blaming and punishing people as voluntary actors is ineffectual in controlling crime, but we are stuck with the morality system and blame because we can see no alternative. If we did away with it, we would be left with forms of persuasion indistinguishable in spirit 'from force and constraint' (ibid). We remain therefore with the devil we know.

In the following passage from Shame and Necessity (1993), Williams speaks of overemphasis on 'the voluntary'. This results from the modern conflation of a particular view of morality and a particular institutional setting, that of the liberal state. The outcome is an impoverished moral theory for morality has been conflated with politics: 
We have handed many of the responses to a very special formation, the modern state, and we have principles governing what such a state can and should do. An important ideal that helps shape those principles is that an individual should, so far as possible, have control over his or her life, in relation to the power of the state.... To the extent that our ideas about legal responsibility are shaped by that ideal, they are governed by a certain political theory of freedom in the modern state, not by a moral refinement of the very conception of responsibility.... We deceive ourselves if we suppose that public practices of ascribing responsibility can be derived from an antecedent notion of moral responsibility, or that the idea of the voluntary is uniquely important to responsibility (Williams 1993, 66-67).

This is Williams's political critique of modern guilt. The weakness of modern orthodox liberal theory resides not just in its intrinsic limitations, but in the fact that its concepts conflate a political aim and setting and a philosophical elaboration. It is because of the unwarranted fusion of morality, law and politics that we can say that one of Williams's targets is the historical and political critique of modern moral and legal forms. From this position, the move is to a critical understanding of the nature of modern liberalism and how it shapes the social order for good and ill. ${ }^{3}$ The second target in light of these limitations is to sketch an ethical alternative in the form of a critique of what he calls moralised psychology.

\subsection{An Ethical Critique: Against Moralisation}

Here, Williams pointed out a different direction to modern morality without taking things very far. He spoke about the need to develop a 'naturalistic account of morality', a term that, he conceded, was not 'at all perspicuous' (Altham and Harrison 1995, 203). What he meant was the difference between a moralised and a moral psychology. In the former, a given moral theory dominated and shaped $\mathrm{ab}$ initio the understanding of human psychology. It gave psychology the concepts to work with, so that the resulting account aped the philosophy it was supposed to develop. Modern morality's emphasis on the voluntary control of action would be a case in point: it appears to represent the basis for an understanding of human moral psychology, but in reality it imposes a particular political and moral theory on psychology, so that it is moralised rather than moral. A non-moralised psychology would relate itself to the open questioning of how humans act, and how their moral categories emerge from behaviours and settings, broadly conceived:

\footnotetext{
3 This is in essence the direction already taken by critical legal theory in relation to criminal law. The result is a political and historical critique of the structure, function and form of the law. See, e.g., Norrie (2000, 2014), Ramsay (2009), Lacey (2016), Farmer (2016) and Carvalho (2017). For discussion of the one-sided nature of this critique, since it omits the ethical direction developed below, see Norrie (2017b). As stated, the present essay focuses on the ethical critique and does not pursue the road already taken of political and historical critique.
} 
A non-moralised, or less moralised, psychology uses the categories of meaning, reasons, and value, but leaves it open, or even problematical, in what way moral reasons and ethical values fit with other motives and desires, how far they express those other motives, and how far they are in conflict with them (Altham and Harrison 1995, 202).

Williams's examples of a naturalistic moral psychology that does not prefigure the end from the beginning are various. They include Hume and Nietzsche, but also writers such as Thucydides, Diderot, Stendhal, and the ancient tragedians, who have a 'powerful understanding of human motivation, in particular of relations between ethical and non-ethical motivations' (Altham and Harrison 1995, 204). But, in this discussion, the first example Williams gives of a modern who had such an understanding is Freud, and we can see how this works in Shame and Necessity, in two ways.

The book involves a contrast between modern guilt and shame, and an underlying contrast between the ancient Greek and the modern standpoint. It is not so much a question of Greek shame versus modern guilt as of how the Greek approach declined to separate the two (Williams 1993, 91). The modern approach does separate them, creating an account of guilt that is narrow and voluntaristic. Shame's quality is that it is more contextual than guilt, permitting understanding of a failing or inadequacy and what it means in an actor's, and in other people's, lives. Modern guilt follows the 'peculiar' moral approach, simply affirming one has done wrong, without a broader understanding. 'Shame can understand guilt', says Williams, 'but guilt cannot understand itself' (Williams 1993, 93). At this point, Williams draws upon 'psychological materials' (ibid), what we can call 'naturalistic elements' for a moral psychology, to illuminate shame and help also with guilt. Here, we can identify psychoanalytic ideas in Williams's argument, though Freud's name goes unmentioned:

Even if shame and its motivations always involve ... the gaze of another, ... for many of its operations the imagined gaze of an imagined other will do.... What I have called the internalised other ... is conceived as one whose reactions I would respect.... The internalised other is indeed abstracted and generalised and idealised, but he is potentially somebody rather than nobody, and somebody other than me. He can provide the focus of real social expectations, of how I shall live if I act in one way rather than another.... The world ... is represented ... by an internalised other... (Williams 1993, 82-85, emphasis added).

This idea of an imagined or internalised other that is in-me-and-not-me involves intrapsychic identification with another. It is taken from psychoanalysis, where, to quote Freud, it 'is known ... as the earliest expression of an emotional tie with another person', one that 'endeavours to mould a person's own ego after the fashion of the one that has been taken as a model' (Freud 1985, 134-135). In Shame and Necessity, Williams develops a moral psychology to explain the ethical quality of shame as it emerges from encounters central to psychic development. 
That is his first encounter with moral psychology, but there is a second, in an addendum entitled 'Mechanisms of Shame and Guilt', a four page endnote that was not integrated into the book. Here, Williams proposes a moral psychology of guilt alongside that of shame, complete with its own particular internalised figure, that of a 'victim or an enforcer'. In line with the protocols of moral psychology, this cannot simply be stipulated or derived as a necessary moral form, but must be traced back to the conditions of psychic development understood in a naturalistic manner:

In the case of guilt, this condition can be met by supposing that, at the most primitive level, the attitude of the internalised figure is anger, while the reaction of the subject is fear.... From this primitive basis, it is possible, by what is sometimes called 'bootstrapping', to develop the model to allow for reactions that are progressively more structured by social, ethical, or moral notions. So mere fear at mere anger becomes fear of recrimination... (Williams 1993, 219).

As we shall see, the strong echo here is to Freud's Civilization and Its Discontents (Freud 1985), where fear of and anger at the father or another authority figure represents the basis of guilt. But Williams was only sketching possible links in these four pages, indicating the bridgehead to moral psychology rather than developing it systematically. It is also important to note that he was drawn to psychoanalytic ideas without having a settled view as to what they were. In the passage I have just quoted, guilt is a fearful or angry result of identification with a victim or enforcer, which evolves into ethically elaborated notions. Elsewhere, however, Williams wrote of the psychoanalytic grounds of moral psychology in different terms:

As soon as we look at blame not as a uniquely appropriate expression of truly moral judgement, and not, on the other hand, simply as an instrument of social control, but see it as part of a concrete ethical life, we shall be helped to understand the other psychological forces (such as love, perhaps) that are needed to make blame possible as a manifestation of the ethical dispositions (Williams 1995, 16, emphasis added).

The passage comes out of the blue in an essay on free will, but significant here is the emphasis not on fear and anger, but on love, a very different basis for feelings of guilt, though one that is developed in the psychoanalytic literature. We will pursue the difference between these two approaches below. This is, then, what we get from Williams: bridgeheads to the political critique of modern morality as socially functional but intellectually shallow and 'peculiar', and to the idea of a moral psychology that would underpin ethical experience, and that would be truthful to what it means to be human in a way that the modern 'peculiar' institution, with its moralised psychology, cannot be. As for what the nature of the moral psychology of guilt should be, however, this is only a start. 


\section{Guilt, Atonement and Identification: Ethical Elements for a Moral Psychology}

Because they have defined themselves in a manner that reveals identification with others, the actions of those others are granted power over them.... Individuals may in these circumstances believe themselves guilty (Morris 1987, 240).

Morris published a book of essays called On Guilt and Innocence in 1976, and he followed this with an essay called 'Nonmoral Guilt' in 1987. From the former, we get the idea of atonement; in the latter, Morris develops the idea of identification. The two ideas can be seen to be closely linked in the understanding of guilt, and Morris also illuminates the difference between legal guilt and a broader metaphysical form that reflects Williams's concern with modern guilt's narrow abstraction and 'peculiarity'. In this section, we consider Morris's view of atonement and identification seriatim.

\subsection{Guilt and Atonement}

Morris's (1976) book is subtitled 'Essays in Legal Philosophy and Moral Psychology', so that his use of the term 'moral psychology' predates Williams's. ${ }^{4}$ In the preface, Morris notes that philosophers have written exhaustively on punishment and responsibility, but their focus is limited to questions of the justification of punishment and the ascription of responsibility. Little attention has been paid to "concepts of guilt and guilt feelings, and ... to the rich assortment of related concepts such as remorse, repentance, contrition, forgiveness and shame' (Morris 1976, viii). The 'complex world of moral feelings, a world so central to our lives, so deep in significance for us, so vividly and thoroughly displayed in literature' has attracted little attention from philosophers. ${ }^{5}$ Morris added that a 'better grasp of guilt and related concepts will mean a more informed judgment of the merits of our common moral and legal practices' (ibid). The division implicit in the subtitle between legal philosophy and moral psychology suggests closeness to Williams's distinction between naturalistic moral psychology and morality as a 'peculiar' institution, and there is much in Morris's account to support convergence. In one short essay on 'Guilt and Shame', Morris writes that, in contrast to shame, guilt 'finds a natural role within the law' (Morris 1976, 63), and this because law maintains 'a certain balanced distribution of freedom ... by ordering relationships among individuals through rules that set up a system of reciprocal rights and duties' (ibid). Though he does not mention the term, this is Williams's realm of 'the voluntary', the space of a moralised psychology under the rubric of legal form, which he contrasts with the idea of shame.

\footnotetext{
${ }^{4}$ In Shame and Necessity (1993, 198, note 35), Williams acknowledges the significance of Morris's work.

5 Murphy (2012) touches on issues in moral psychology especially where he engages with Morris's work.
} 
In this essay, however, Morris accepts the nature and the form of law as the home of modern guilt. Yet, in the next essay, 'Guilt and Suffering', he takes guilt in a different and contrasting direction. Here, the account of guilt is both more personal and more metaphysical, and it is at odds with how he described it in the previous essay. Here, guilt is not legal guilt, but is instead psychic and somatic: it means feeling bad, 'rotten, depleted of energy, tense' (Morris 1976, 99), for ethical reasons. The core idea is of real emotional pain that comes from separating oneself off by an act of violation from union with a valued other. Such union, best exemplified in love, provides a feeling of wholeness or completeness, while guilt relates to a wholeness that is broken and undone:

In seeing oneself as cut off from others one feels a sense of incompleteness, as a lover who loses a loved one may feel that a part of him has been taken away or torn from him. The person feels that peculiar pain and uneasiness when feeling guilty of cutting off a part of himself.... In cutting oneself off from others one comes to see oneself as being cut off, not whole, as if one had destroyed what one loved and thus also destroyed a part of oneself. This image of cutting off and being cut off, not whole, finds support in our view of the guilty person as not being able to function as a whole person could and does, not being able to enjoy life fully... (Morris 1976, 99-100).

Guilt weighs on a person who has brought such feelings on himself. The emotional pain of the broken self presses for ways to restore wholeness, to return to being at one with oneself and others:

To feel relieved of guilt is to feel again that one is joined together with others and with oneself, to no longer be divided within and at war with ourselves and others. This need to make amends, to mend what has been damaged, and to be at one again with others and oneself is at the core of guilt. If it is successful, it is atonement, being at one with (Morris 1976, 100, emphasis added).

To atone is to return one's guilty self to a state of wholeness, to restore the lost connections, to be back to being 'at one'. This is the original meaning of atonement and it involves for Morris moral, emotional, psychic and somatic pain both in coming to acknowledge one's wrongdoing, and also then in seeking to address it. It is the pain of self-anger and shame at what one has done; it is a consequence of acknowledging to oneself that one was in the wrong; and it is what makes genuine confession or contrition so hard, just as the release they eventually bring is genuinely felt as a weight lifted.

As I have stressed, Morris suggests a link between the psychic and the somatic. Moral contrition is a matter of pain, manifested as feeling rotten, depleted of energy and tense. Emotional pain is felt as embodied, pointing to the kind of connection that a Williams-style moral psychology would expect to find as it builds up from psychic states that are rooted in physiological conditions. This thinking 
is very much in line with psychoanalysis. ${ }^{6}$ Important too is the line that Morris draws between this account of guilt and guilt in law. The pain "we suffer when feeling guilty and the pain involved in the expression of those feelings differs from pain that is inflicted with the significance for us of punishment' (Morris $1976,104)$. The essence of legal punishment lies in a deprivation with a meaning that is communicated to the person who is to be punished. It is deliberately inflicted pain for wrongdoing, but it is not restorative of a sense of individual wholeness. It may be viewed as restoring a 'certain disrupted rule-established equilibrium of benefits and burdens', but this value of completeness in 'impersonal, reciprocal legal situations' (ibid) is very different from the wholeness that the moral psychology of guilt seeks. In this latter setting, the value of punishment to the requital of guilt is 'non-existent, insignificant, or positively perverse', for here we consider guilt and atonement in a context akin to 'where a friendship or love relationship based on affection, respect, and trust has been damaged' (Morris 1976, 105). The point is that ethical guilt of this sort and the restoration of wholeness is at odds with the functioning of an inculpatory legal process leading to punishment:

While punishment might be seen as restoring a rule-established equilibrium of benefits and burdens by taking from the wrongdoer benefits not permitted him, it is never by itself restorative of relationships that are defined by feelings and commitments. Something must come in these relationships from the injured party if ever there is to be restoration-forgiveness. But something of course must also come from the guilty party, [in terms of] restorative responses (Morris 1976, 105-106).

Now we are quite clearly in the territory sketched by Williams of a naturalistic moral psychology that would grasp the ethical feelings that guilt invokes. The value of Morris's account is his linking of the ethics of guilt taken at a metaphysical level to the moral feelings of a person and a body. Note also that, comparing the two, Morris's psychological route is from love rather than anger. In this way, he not only distinguishes guilt in a moral-legal sense (Williams's 'peculiar' institution) from a deeper ethical guilt (in line with moral psychology), he develops the latter substantively in ways that link moral experience to emotional feeling. He additionally brings the psychic and the somatic together around the idea of love, and finds guilt and reparation at this level, and in contrast to the logic of guilt in the law.

\section{2 'Nonmoral’ Guilt and Identification}

Morris's account may, however, invite a question. He notes the desire to restore wholeness that lies at the root of guilt and he links this to an account of love ['as a lover who loses a loved one may feel that a part of him has been taken away or torn

\footnotetext{
${ }^{6}$ Consider here Jonathan Lear's wonderful summary of Freud as setting out to solve 'the mystery of the flesh made word' (Lear 1990, xii).
} 
from him ..., as if one had destroyed what one loved and thus also destroyed a part of oneself' (Morris 1976, 99)]. But a person who for example violates a stranger may feel guilty for what he has done, and while one may talk of loving a stranger, this may be thought to stretch the analogy. One may wish for more 'psychological material' to explain how the moral psychology works with regard to guilt in relation to strangers. This brings us to Morris's account of identification in his 1987 essay. This has the intriguing, somewhat question-begging, title 'Nonmoral guilt', which indeed emphasises precisely Williams's point that there is a particular contrasting way of speaking about guilt in law, which is termed 'moral guilt'. ${ }^{7}$ This is none other than Williams's 'peculiar' guilt, based on voluntary control of agency, and which contrasts with the broader sense of guilt Morris calls 'nonmoral'. ${ }^{8}$ Such a broader sense Morris developed in the 1976 book; in the 1987 essay, he draws on it to cover situations where a person may feel guilt at a distance without having acted in a legally culpable way. Nonmoral guilt occurs, for example, where someone has been the unwitting beneficiary of bad outcomes for others, or complicit in a distanced and non-active way with a bad action, for example, committed by one's country or historically, by one's parents' generation. Morris considers such feelings of guilt for matters distant from one's acts to be morally appropriate.

Why should one feel guilt when one has not acted? Nonmoral guilt, guilt that is not based on moral culpability because in control of one's voluntary actions, exists because nonetheless one identifies with another, and this is the psychological mechanism that links feelings of guilt with a sense of love or wholeness with others. This cannot be called 'moral guilt', if we accept that moral guilt involves the voluntary control of an action, yet it is an ethical guilt, which Morris uncomfortably describes as nonmoral:

Feeling guilty, then, would both mark one's attachment to principles of fairness and justice and manifest one's solidarity with others. While nonmoral, it would derive from a moral posture toward others. One's feelings would track the scope of one's identificatory ties with the less fortunate, those before whom one feels guilty... (Morris 1987, 237).

The key idea here is not that of a simple sympathy with the other, imagining her experience, but rather involves the deeper intrapsychic reality of entering into the experience of the other with whom one identifies:

An identification with others, then, may be operative that is not limited to particular aims or dispositions that have led to evil... One's identification with another implies, for example, that we suffer when they do, just as we are pleased when they are. We imagine their feelings, thereby 'entering into' them. We have the feelings we imagine them to be having as contrasted with our

\footnotetext{
7 Murphy $(2012,98)$ calls Morris's choice of terminology 'unfortunate' for allowing a Kantian ethic of voluntary wrongdoing 'to gobble up the entire domain of morality'. Unfortunate, but also perhaps affirmative of Williams's political critique of modern morality.

8 Morris explains 'moral guilt' as the limited idea of culpable responsibility for wrongdoing, involving 'the intentional transgression of prohibition ... by a definite voluntary act' (Morris 1987, 220).
} 
merely responding in an appropriate way, say with sympathy, to the feelings we imagine them to be having... (Morris 1987, 239).

This entering into the mind and experience of the other does not mean we become the other. We retain 'our own identity at the same time as we identify with' (ibid) that person. This is Williams's imagined or internalised other who is in-me-and-notme, but whereas Williams deployed the idea to think of the voice that speaks or the observer who sees, Morris uses it to explain why a person might feel for or identify with the violation, victimisation or suffering of another, and therefore might feel guilt for her violation. Where another, for example, a parent, has been a perpetrator,

[i]dentification would have us imagine what our own reactions would be were we the wrongdoer.... [T] he process of identification, once operative, carries a psychological momentum so that, in identifying with the person engaged in wrongdoing, one imagines how one would oneself feel.... [These] feelings connected with identificatory processes are often perfectly normal, and it is their total absence that may occasion concern.... Because they have defined themselves in a manner that reveals identification with others, the actions of those others are granted a power over them.... Individuals may in these circumstances believe themselves guilty (Morris 1987, 239-240).

When one identifies with another in Morris's account, one moves from a sense of wholeness and solidarity with another, and on that basis one 'enters into' another; and the entering into another is also the taking of the other into oneself. ${ }^{9}$ The move of identification is both inward-outward and outward-inward, and this is because the initial idea is of the self that is linked to the other by love, wholeness or solidarity. In this way, Morris combines his earlier account of guilt as the fracturing of wholeness leading to atonement ('at-one-ment') (Morris 1976, 100) with an understanding of the mechanism by which the fracturing is experienced (identification). In the process, he brings us close to the 'psychological materials' we need to think about guilt. What would now be needed would be a development of those materials at a deeper level, and this beckons us to the realm of psychoanalysis and Freud, where Williams has already invited us to go.

\section{Metapsychology as Philosophical Enquiry}

Psychoanalysis is the flourishing human activity of the rational soul taking immediate, poetic, and practical responsibility for the nonrational soul. Other names for this activity are ... truthfulness, rationality, freedom and eudaimonia (Lear 2017, 47).

But why should we accept Williams's invitation? One reason would be that his and Morris's accounts have taken us to the edge between philosophy and psychoanalysis.

\footnotetext{
9 Identification on Morris's examples can be with both a perpetrator and her guilt, and with a victim and her violation. The general question is why one might feel guilty for acts or situations that involve distance from either one's acts or immediate emotional commitments, if guilt is based on fractured love.
} 
The spirit of truthful enquiry might push us on, realising that we must shift disciplines to see the whole picture, but requiring us to leave the domain of philosophy. A second reason that might be more persuasive, for philosophers at least, is provided by Lear, who argues that the move into psychoanalysis is a way of developing philosophical enquiry according to philosophical criteria. In accepting Williams's invitation, we are extending philosophy appropriately, not moving to another field.

\subsection{Philosophy at the Brink}

From Williams, we have the idea of a 'peculiar' morality that dominates modern ethical thinking, and which is limited in scope and depth by its yoking to a specific institutional framework. Williams's critique of that institutional morality goes in two directions. The first is towards politics and history, the second towards an underlying ethical or moral psychology which would ground ethics in human psychology and not via the pre-formed dictates of a political institution. Such a psychology should attend to the 'psychological material' involved in human reactions and relations, though precisely how 'the moral' and 'the psychological' should be configured remains unclear.

Nonetheless, Freud by name, and psychoanalysis by nature, play an important role in Williams's rudimentary moral psychology. In Morris, we see a similar outcome by a different route. Morris has no critique of a 'peculiar' institution, but he does have a critical understanding of guilt, which he develops by showing the limits of voluntariness as the base category in blame and guilt theory. Calling this 'moral guilt', he develops a second 'nonmoral' form, which emphasises the breaking apart of the self, the search for wholeness through atonement, the basis of wholeness in love for the self and the other, and the importance of identification with the other as guilt's source. The only complaint one could have about Morris is that he calls this a 'nonmoral' theory, for plainly it is not; yet the terminology makes Williams's point that theory remains in thrall to a superficial concept, that of the voluntary. Identification is the key to nonmoral guilt, and it is also a key element in psychoanalytic theory, so Morris has introduced a concept that indicates a provenance that Williams would have us explore. That both Morris and Williams refer to the basic psychological mechanism of an intrapsychic dialogue with another that is a part of the self but takes the form of another's voice indicates their joint direction of travel towards psychoanalysis.

\subsection{From Metaphilosophy to Metapsychology}

If we connect psychology and ethics around guilt, is it a question of a non-philosophical add-on or can the psychoanalytical element become a part of a fuller, more rounded, philosophy? Lear is remarkable as a philosopher with a profound understanding of Greek philosophy (e.g., Lear 1988), and as a psychoanalyst who has developed an original interpretation of Freudian psychoanalysis (Lear 1990), which he links to Greek philosophy (Lear 1998, 2015, 2017). Drawing on the 
psychoanalytic work of Loewald (1980), ${ }^{10}$ Lear develops an account of Freud that emphasises the importance of his later structural theory of mind, and the importance within it of an understanding of how the force known severally as love, Eros, the life drive, or libido evolves as it is 'enformed' through relations with others. Here, identification plays a central role, and from this work, we can see how an expansion of philosophy to include 'psychological materials' becomes philosophically possible.

Here, Lear's distinctive approach is to align an interpretation of Freud with Aristotle. He seeks to engage the 'rational' and 'non-rational' sides of the psyche, in order to follow the Socratic injunction to know, and to be true to, oneself as the basis for a flourishing, eudaimonic, life (Lear 2015, ch. 1). Lear views Freud as implicitly at least pursuing an essentially philosophical, and within that, specifically Greek project. In the first book of his Nicomachean Ethics, Aristotle raises the philosophical question of the relationship between the rational and the non-rational parts of the psyche (Aristotle 1984, 1741). However, Aristotle possessed a weak analysis of that relationship, which psychoanalysis is able to develop with its own account of the relationship between the conscious and the unconscious mind. Psychoanalysis is thus a modern discipline rooted in an ancient philosophical quest:

Philosophy has long considered human life to be distinctive (and valuable) in virtue of its capacity for self-conscious awareness.... From the time of Plato and Aristotle ... one of reason's central tasks has been taken to be the thoughtful, self-conscious integration of the human psyche. The point is not merely that psychoanalysis provides insight into how such integration might be achieved - far beyond anything Plato or Aristotle imagined-it is that psychoanalytic activity itself is the very exercise of self-conscious, thoughtful integration of the psyche.... Psychoanalysis gives us unparalleled access to the microcosm of reason's working at the interface of (what Aristotle called) the rational and non-rational parts of the soul (Lear 2015, 212).

Psychoanalysis is no more nor less than the modern continuance of the ancient quest for the rational achievement of happiness. Viewed from this point of view, the relationship between reason and the non-rational ${ }^{11}$ is specific. It involves more than reflection upon, control over, or judgment of the passions, emotions and inclinations. The move is not one of Kantian withdrawal in order to critically reflect on natural impulses ${ }^{12}$; nor is it a question, as it is in Aristotle's practical ethics, of refinement of and training in virtuous practices; rather it involves acknowledgement of,

\footnotetext{
${ }^{10}$ On Loewald, see Mitchell and Black (1995, 186-193), and Mitchell (1998).

11 In Freudian terms, this becomes the engagement between the conscious mind and the unconscious mind.

12 Murphy $(2012,239)$ takes up the Kantian line when he writes: 'Freud and other psychoanalysts talk brilliantly about the infantile origins of our loves, but surely one of our missions-as autonomous and rational human beings - is to attempt to transcend the limitations imposed by those origins, not to surrender to them.' Between transcendence and surrender, there is living and knowing engagement with that which remains a part of us. How could, and why would, Murphy (2012, 107-113) reflect movingly on the ongoing quality of his own bad conscience, on shame and ego ideals, had he truly transcended his childish origins, and should he attempt so to do?
} 
and reasonable engagement with, a part of the psyche that has its own reasons. The aim is for the rational and non-rational sides of the human psyche to be constructively engaged in a way that permits a person to act with a degree of unity of the self, hence to be true to the self. This permits one to be self-reflective in action, and, on that basis, to be in the best position to flourish as a person. Freud 'simply', one might say, helps us pursue Socrates's injunction that we should before all else know ourselves, so that the key value in psychoanalysis is truthfulness about the self, both in terms of what we know of the self, and how we act. We learn about ourselves, about the interconnection of and engagement between our rational and non-rational parts, in order to be true to who we are, to follow the Greek commitment to a unified psyche, and to achieve a stronger, more completely free, because integrated, agency:

In this way, psychoanalysis can be seen as an attempt to resume the ancient project of an ethics and politics grounded in and explained by a robust conception of human flourishing. This is the project the ancient Greek philosophers could not themselves complete (Lear 2015, 17).

Other names for psychoanalytic activity are 'truthfulness, rationality, freedom and eudaimonia' (Lear 2017, 47). The claim to truthfulness picks up Williams's aspiration for a 'truthful ethical life', which, he says, has always been 'one that can include our best understanding of our psychological life' understood naturalistically (Williams 1995, 19-20). The question then would be: how does this relate to the understanding of guilt as we have developed it above, in terms of atonement and identification? In delving into the psychoanalytic understanding of guilt, I believe we can hope to deepen our grasp on how guilt functions as a human response, and that would be a philosophical enquiry, under the Socratic injunction to know ourselves, in order to act with greater self-awareness and therefore freedom.

\section{Guilt, Pleasure and Happiness}

[On] a familiar reading of Freud's Civilization and Its Discontents, the world is not a place that is conducive to human happiness. And ... the aim of civilization ... is to keep us in line.... This reception has become boilerplate; one of the joys of Loewald's writings is that he offers a different choice of inheritance (Lear 2017, 193).

From Williams and Morris, we have the idea that the intrapsychic reality of the guilty person involves a relationship with another. This could be the angry internal voice that makes us feel bad (the victim, the enforcer) (Williams), or it could be the feeling of entering into another in order to identify with her pain, which then becomes our pain (Morris). Though they have similar kinds of expression as painful feeling, these are not the same forms of interiority. Williams's internal other is angry and guilt comes from fear of that anger, but it will be recalled that elsewhere, Williams thought that love might be at the heart of the psychological reaction that leads to guilt. Love is much more the key to Morris's account. The person identifies with the other by seeing herself as, putting herself in, that other, and feeling either as she 
might feel (as a victim), or according to what she has done (as a perpetrator). Identificatory guilt is feeling emotional or somatic pain, and pain is related to the breach in wholeness that is a loss of emotional unity in oneself and with others. Identificatory guilt is about the loss of wholeness that comes from love of self in relation to the other, and it results in psychic and somatic pain.

In this section, I consider how these two conflicting routes to guilt (anger/fear and love) reflect discussion around identification in psychoanalysis itself. I begin with Freud's predominantly anger-based approach in Civilization and Its Discontents but note a conflicting love-based approach. ${ }^{13}$ Underlying the difference is an unresolved conflict between understanding the psyche in terms of pleasure and happiness.

\subsection{Guilt in Civilization and Its Discontents: Repression, Anger, Fear}

The difference between love and a combination of anger and fear as the ground of guilt is important because it reveals two roads down which a psychoanalytic understanding of guilt might travel. In Freud's own thinking, it would appear that it is fear and anger that lie at the heart of guilt, but we shall see that this is not necessarily the case. Nonetheless, if we consider Freud's account where he most clearly set it out, in Civilization and Its Discontents, it is guilt as resulting from aggression, fear, and anger that is at the centre. In the following two passages, for example, Freud identifies two sources of guilt. One involves fear at the angry response of an authority figure, the other involves an angry resentment at having to suppress one's desires, which gets turned back onto oneself (introjected) as the development of a harsh super-ego:

Thus we know of two origins of the sense of guilt: one arising from fear of an authority, and the other, later on, arising from fear of the super-ego. The first insists upon a renunciation of instinctual satisfactions; the second, as well as doing this, presses for punishment, since the continuance of the forbidden wishes cannot be concealed from the super-ego. We have also learned how the severity of the super-ego - the demands of conscience-is to be understood. It is simply a continuation of the severity of the external authority, to which it has succeeded and which it has in part replaced (Freud 1985, 319).

\footnotetext{
13 Any serious account of Freud on guilt will have to reflect the conflicts in his account. Deigh (1996) takes his analysis from what Freud says in Civilization and Its Discontents, and then acknowledges that the account there is hard to square with Freud's general position. Accordingly, he finds a 'Nietzschean' account of super-ego formation and thence guilt in Civilization, which compares with the 'standard' account elsewhere. The difference concerns the role of the Oedipus complex in creating the super-ego, which is unimportant in Civilization but central elsewhere. (It appears once, in discussing the story of the band of brothers who kill their father, but not in relation to the super-ego.) As we shall see, it is central to Hans Loewald's account, in a more extended, less sex/gender focused, version than Deigh describes. Deigh is not wrong to find a different account in Civilization than elsewhere; where we differ is with regard to how that difference is to be explained. From my point of view, the underlying conflict is between the earlier stimulus satisfaction, pleasure-based, account, and the later structural theory, grounded in love and ego formation. Deigh notes the difference between earlier and later Freud, but does not build on it. In my view, the 'Nietzschean' account Deigh describes is descriptively valid, but leaves Freud in a cul de sac with regard to a plausible ethics of guilt, as Murphy (2012, 96-97) suggests.
} 
In this rather bleak analysis, human beings are forced by nature to repress their instincts in order that society might be possible. Civilization is a necessary but an uncomfortable place to be. Aggressiveness is at the core of human agency, but it becomes internalised through the super-ego, "which now, in the form of "conscience", is ready to put into action against the ego the same harsh aggressiveness that the ego would have liked to satisfy upon other, extraneous individuals', and this is the basis of 'the sense of guilt; it expresses itself as a need for punishment' (Freud 1985, 315-316). In this setting, the individual achieves a sense of guilt by identification with the anger of authority figures, which he internalises:

A considerable amount of aggressiveness must be developed in the child against the authority which prevents him from having his first, but none the less his most important, satisfactions ...; but he is obliged to renounce the satisfaction of this revengeful aggressiveness. He finds his way out of this economically difficult situation with the help of familiar mechanisms. By means of identification he takes the un-attackable authority into himself. The authority now turns into his super-ego and enters into possession of all the aggressiveness which a child would have liked to exercise against it... (Freud 1985, 322, emphasis added).

Where Freud speaks of guilt through identification, one can see how it links with Williams's comments about fear and anger, but it is nothing like the identificatory connection described by Morris. For Morris, identification is related to love and wholeness, not fear, aggression and resentment at authority. The identificatory impulse in Morris seeks to find wholeness again, working through the pain that a breach of unity between self and other has brought. For him, anger at self may ensue, but it is not based on introjected fear or resentment. So, on the face of it, Freudian psychoanalysis is unlikely to provide the route to an understanding of the psychology of guilt that can take us to Morris, or to Williams when he talks of love, though it could ground an understanding of the angry voice of the victim or the enforcer that was Williams's other suggestion for the source of guilt. Identification can thus be linked either with love and wholeness or with fear and anger, but in Freud, it is the latter connection that is to the fore.

\subsection{A Secondary Route to Guilt: Love and Identification}

There is, however, a secondary route to guilt in Civilization and Its Discontents, which does involve love and loving identification. We may approach this through the interpretation of Freud developed by Lear and Loewald, whose accounts centre on love, a theme that is explicit, but unevenly developed, in Freud (Loewald 1980; Lear 1990, 1998, ch. 6).

In his Freud (2015), Lear suggests that there was a reason Freud was unable to develop fully the ancient Greek agenda implicit in his work described above. This was because he adopted, and failed to distinguish, two contradictory approaches to metapsychology, one resting on the significance of pleasure, the other on the importance of happiness (Lear 2015, 197-199). The latter takes Freud towards Aristotle, 
but the former remained dominant in his work. The importance of pleasure rested upon a modern 'scientific' understanding of human behaviour, which emphasised the importance of instinctual, including sexual and aggressive, impulses which sought satisfaction, and which had to be repressed or sublimated if civilization was to be possible. This was a mechanistic, scientistic, nineteenth century model of human behaviour, emphasising the pursuit of pleasure, understood as the satisfaction of impulses, desires and instincts. It was quite distinct from a model that would find itself linked to the kind of Aristotelian approach identified by Lear, one in which love and eudaimonic happiness, based upon the engagement of the rational and the non-rational sides of the psyche, are to the fore. It is the pleasure-based approach that underpins the account of guilt as rooted in fear and anger that we find in Freud.

But the approach that could develop the Greek account of happiness is also present in Freud's thinking, developed in his later structural account of how the ego and the super-ego emerge from the earliest, protean, period in a child's life, where an undifferentiated love begins the human journey as libido, a basic, unformed, life drive. Freud named this early phase of human life 'primary narcissism', but the term does not have its modern reference to an overdeveloped self-regard. ${ }^{14}$ The basic argument is from The Ego and the Id (Freud 1984), in which the ego and the superego represent important differentiations in the evolving structure of the mind. These enable the person to develop as an autonomous, self- and other-loving being. Key to this development is the 'enforming' of the initially formless libido as both an ego and then, within the ego, a further differentiation that is the super-ego. This is a process wherein the child identifies with parental figures in order to take them in as 'ego-ideals', and to refashion them as building blocks in the child's own selfidentity. In this structural theory of the mind, loving identification with parental and other figures permits the child to grow as an autonomous being in its own right. This is the point of the quotation used in Sect. 1.3, that identification is the 'earliest expression of an emotional tie with another person', moulding 'a person's own ego after the fashion of the one that has been taken as a model' (Freud 1985, 134-135).

Now, turning back to the question of guilt, there are indications of the importance of this 'happiness-based' line of thought in Civilization and Its Discontents alongside the pleasure-based themes that we have described above. The first section of the work is indeed given over to an account of the development of the ego out of a field of inchoate love. In the following passage, for example, the ego is formed out of basic connections between an infant and a parent in which the infant begins with a basic life force or libido, an inchoate and primal love for life, the phase of primary narcissism. Loving interaction with parental figures creates a gap between what becomes (through ego formation) an infant's own internality and what (as a result) becomes external to it:

An infant at the breast does not as yet distinguish his ego from the external world as the source of the sensations flowing in upon him. He gradually learns to do so, in response to various promptings.... In this way there is for the first

$\overline{14}$ A point noted by Murphy $(2012,111$, note 27) in the punishment literature. 
time set over against the ego an 'object', in the form of something which exists 'outside'.... One comes to learn a procedure by which ... one can differentiate between what is internal-what belongs to the ego-and what is externalwhat emanates from the outer world.... In this way, then, the ego detaches itself from the external world. Or, to put it more correctly, originally the ego includes everything, later it separates off an external world from itself (Freud 1985, 254-255).

Frustratingly, Freud does not pursue this theme into an understanding of guilt. Guilt remains stubbornly linked to aggression, fear and anger in the way we have described. There is, however, a point in the text, where he finds himself at a loss, and reaches for love as an explanation of guilt. It is the point where Freud revisits the story of the 'band of brothers' who in the earliest time kill their father. This is the 'phylogenetic' story of early human life, involving an extension of what Freud said in Totem and Taboo (Freud 1990) about the origins of humankind. It concerns the fact that 'man's sense of guilt springs from the Oedipus complex and was acquired at the killing of the father by the brothers banded together' (Freud 1985, 12, 324). This story of the origins of guilt is problematic for its speculative and mythic quality, but it is important for how Freud depicts the relationship between guilt and love. In the original relationship, sexual rivalry, aggression and hatred lead the sons to kill the father. This leads to a question in terms of Freud's account of guilt: why should the sons feel guilty? If they have deployed murderous aggression towards the father, then they have not internalised the prohibition against killing, and nor have they introjected their aggression, which would be a further source of guilt feelings. The internalisation of guilt has not taken root: why then should the sons feel guilty for their father's murder?

Freud initially negotiates this question by suggesting there is a difference between feeling remorse and feeling guilt, but he acknowledges that remorse, like guilt, presupposes the existence of a conscience (ibid). ${ }^{15}$ In the end, he asks: where does remorse come from if neither it nor conscience had been internalised as fear and anger before the deed? His response is to turn to love, because, it now turns out, guilt might not only be about the internalised control of the harsh super-ego. Rather, it 'was the result of the primordial ambivalence of feeling towards the father. His sons hated him, but they loved him, too' (Freud 1985, 12, 325, emphasis added). After their hatred had been satisfied by their aggression, 'their love came to the fore in their remorse for the deed' (ibid, emphasis added). It was their love that 'set up the super-ego by identification with the father; it gave that agency the father's power' (ibid). In this alternative explanation of guilt, we see 'the part played by love in the origin of conscience and the fatal inevitability of the sense of guilt' (ibid). But this is a different route to guilt, the route of love, or Eros, rather than fear and aggression.

\footnotetext{
15 Deigh (1996) seeks to reconcile a fear and anger-based approach with a love-based one by portraying guilt in terms of infraction of an authority's rule, while remorse is linked to feelings of love. But it is not clear that Freud attached such significance to the distinction between guilt and remorse. There is a problem here, but it is the problem of how to introduce the love-based approach to rescue the phylogenetic story, given the overall setting of guilt in Civilization on what Deigh calls 'Nietzschean' lines.
} 
Now Freud builds love into his account of guilt. The sense of guilt now becomes 'an expression of the conflict due to ambivalence, of the eternal struggle between Eros and the instinct of destruction or death' (Freud 1985, 12, 325). But where did love come from in psychoanalytic terms if it was not presaged in the pleasure-based account of the control of the instincts through guilt? If we wish to base our theory of guilt on the 'part played by love', we must follow Freud's concession away from the pleasure approach and towards what Lear calls 'happiness'. This will take us into a discussion of the psychic structure that links atonement and identification in Morris's ethical account with the same terms as used in psychoanalysis, and in which, we shall see, the super-ego plays an important part.

\section{Guilt, Atonement and Prospective Identification}

Guilt then is not a troublesome affect that we might hope to eliminate in some fashion, but one of the driving forces in the organisation of the self. The self, in its autonomy, is an atonement structure, a structure of reconciliation, and as such a supreme achievement (Loewald 1980, 393-394).

The question we must now address is how to link the theory of happiness, love and identification that we find in Loewald's and Lear's accounts of Freud to the account of guilt, love, atonement and identification in Morris. Here, we hit an initial problem, that what Freud says about guilt in his Civilization and Its Discontents mainly takes the road of guilt as a response to fear and anger, where these are introjected, to become the internal voice of the authority figure, the angry enforcer. The route to Williams's moral psychology of the victim or the enforcer may be open, but not to Morris's account, unless we find a way of building on the secondary approach to love and the problem of guilt in the band of brothers in Civilization and Its Discontents. Here, we should wish to put together Freud's later, unevenly developed, structural theory of love and ego formation, converting primary, unformed love into ego and super-ego formation, with an account of guilt as based on loving identification with another. There is a route to be pursued here, and it is through discussion of the nature of the super-ego and its role in fostering guilt. This role may be observed in both an anger-based account and in the love-based approach promoted by Lear and Loewald. In this section, I begin by outlining the role of the super-ego in the angerbased approach and then turn to how it may be developed in line with loving identification, in the work of Loewald.

\subsection{Guilt and the Harsh Super-Ego}

The anger- and fear-based approach to guilt that we have already rehearsed owes its provenance to the pleasure-based account of the human instincts. Pleasure is about instinct satisfaction, and since the instincts are of various kinds and include sex and aggression, repression and the sublimation of the instincts loom large in this model. Such an approach enlists non-sexual love as a means of converting aggression into peaceableness, but that is not at all the same as building emotional reactions on the 
basis of a primary love and the enformed structures that organise it for ego development. ${ }^{16}$ Human beings in the pleasure view are ill-equipped to coexist and need civilization to control aggression. That is the main story of Civilization and Its Discontents, and it enlists the super-ego as the internal figure that represses and controls. Conscience is the introjection of the 'same harsh aggressiveness that the ego would have liked to satisfy upon other, extraneous individuals', and it takes the form of a special agency that is an unpleasant super-ego:

The tension between the harsh super-ego and the ego that is subjected to it, is called by us the sense of guilt; it expresses itself as a need for punishment. Civilization, therefore, obtains mastery over the individual's dangerous desire for aggression ... by setting up an agency within him to watch over it, like a garrison in a conquered city (Freud 1985, 316-317).

The metaphor that ends this passage is telling, for the super-ego is that garrison, and its judgments are not only the external that has been taken inside (recall Williams's account of 'the enforcer' here), it is a harsh form of judgment reflecting the aggressiveness and the resentment that is felt by the individual against his own repression, as well as the society's anger against him. This makes for a grim image, and it is complemented by the following passage, which links this malign force with the philosopher Kant:

The super-ego - the conscience at work in the ego-may then become harsh, cruel and inexorable against the ego which is in its charge. Kant's Categorical Imperative is thus the direct heir of the Oedipus complex (Freud 1984, 422).

Why the Oedipus complex should be introduced here, and whether this is a necessary representation of Kant is not the point. ${ }^{17}$ The point is that, for Freud, following through on repression of the instincts in the pleasure-based approach, the character of the super-ego is harsh and aggressive towards the ego. But, then, is another approach to the super-ego possible within the Freudian canon, one more reflective of Aristotle than Kant?

\subsection{Guilt and the Benign Super-Ego ${ }^{18}$}

As we have seen, the alternative approach based on happiness develops the account of how the early diffuse feelings of love as the initial emotional state of the human

\footnotetext{
16 Down the pleasure and instinct route, sexual love demands satisfaction, while non-sexual love operates to dilute and sublimate sexual and other aggressive demands. See Freud's discussion in Civilization and Its Discontents: Freud (1985, 274-326).

17 The Oedipus complex is not, as noted above, discussed by Freud in his account of guilt in Civilization, save marginally. It should be noted that this quotation comes from the 1924 essay, 'The Economic Problem of Masochism' (also published in Freud 1984), and not from Civilization. For the view that Kant's account of punishment reflects both human dignity and a harsh sense of judgment, see Norrie (1991, ch. $3)$.

18 I owe the idea of a contrast between 'good' (benign) and 'bad' (harsh) super-egos and the guilt they generate according to the pleasure and happiness models of psychic development to Carl Auerbach.
} 
being is nurtured by parental and other figures as they share their love with the child. Doing so, they produce in it a sense of its own identity as worthy of love, self-loving and capable of loving others. For the child, parental figures' existence as individuated loving selves becomes the first identification by which it 'takes in' another in order to establish its own individuated being. It forms itself absorbing from others, so that a sense of identity and autonomy becomes possible, paradoxically, by reliance on those others who love and care for it. Through this process, an ego is formed out of early, inchoate, primary love (narcissism). We saw above how in the first chapter of Civilization and Its Discontents, Freud described this process, but he did not pursue it in his account of guilt. How to connect the two?

There is an answer to this question in two parts in Loewald's account of the relationship between the ego and the super-ego, which draws on, first, what Freud called 'ego ideals', and, second, his (Loewald's) account of the super-ego as an atonement structure (Loewald 1980, ch. 23). In both situations, the underlying relationship is based upon identification between the ego and the other, as this is mediated by the super-ego. But the super-ego has a very different mien than the harshness described above. In the happiness or love-based approach, the super-ego provides coherence and oversight of ego activity as follows. It emerges as a special agency of the ego, coming out of the resolution of the Oedipus complex. ${ }^{19}$ This is well known to involve a child coming to terms with issues of sexual identity associated with its parents. More than this, it is an account of how a child gains a more complex and coherent sense of its own autonomy. The super-ego's formation is a sexual phase that involves father- and mother-identifications, but it is also the phase in which is formed a 'precipitate in the ego, consisting of these two identifications in some way united with each other', giving rise to a special agency that 'confronts the other contents of the ego as an ego ideal or super-ego' (Freud 1984, 373). The super-ego is a means of organising the self at a higher level than the ego, by producing a measure of overall coherence by means of a supervening element within the ego itself, able to organise ego activity. ${ }^{20}$ The result is that the formation of the super-ego equips the individual with both a sense of responsibility and, we shall see, a sense of guilt.

\subsection{Responsibility, Guilt and Ego Ideals}

For Loewald, the development of a super-ego integrates the broad identifications that the child takes in from both parents, but it does so in order to form a sense of personal responsibility:

Responsibility to oneself, within the context of authoritative norms consciously and unconsciously accepted or assimilated from parental and societal sources, is the essence of superego as internal agency.... It involves appropri-

\footnotetext{
19 Thus the two accounts of the super-ego, as harsh and as benign, are both linked with the Oedipus complex.

${ }^{20}$ For this reason, super-ego formation, like the ego formation that precedes it, 'implies an abandonment of sexual aims, a desexualisation' (Freud 1984, 11, 369). More broadly, the complex can be generalised to a deeper level than that of sexual identity or family structure, as a 'childhood florescence of ambivalence towards the important people in one's life' (Lear 2015, 180), regardless of gender or sexual desire.
} 
ating or owning up to one's needs and impulses as one's own, impulses and desires we appear to have been born with or that seem to have taken shape in interaction with parents during infancy.... [So doing] we begin to develop a sense of self-identity [which] means to experience ourselves as agents, notwithstanding the fact that we were born without our informed consent and did not pick our parents (Loewald 1980, 392).

Given responsibility, we are now at the place where internal ego ideals can generate guilt (c.f. Murphy 2012, 292). The term 'ego ideal' was not used consistently by Freud, but one thing it referenced was the models of what was admirable in parental figures that the child took in as the basis for its own aspirations as to how it should behave. Once the super-ego is formed, such ego ideals can become the basis for tension between what the child aspires to be and what it is, and this can lead to a negative super-ego reaction in the

form of tension between ego and superego. We have a sense of guilt concerning past or present thoughts, feelings and deeds, but only inasmuch as they represent a nonfulfillment of the inner image of ourselves, of the internal ideal we have not reached (Loewald 1980, 273-274).

The idea of a tension between the ego and super-ego is, of course, also there in Freud's account of the harsh super-ego in Civilization and Its Discontents. In Loewald, it is not the angry voice of the external authority figure introjected into the super-ego, but the internal tension brought about by not behaving as one would like to at one's best. ${ }^{21}$ This is one aspect of a guilt that a person would feel for doing a wrong act-not as external repression absorbed to deal with anger, but as something having an ethical ground in loving admiration of the good qualities of parents, as the feeling that one has done badly according to parental standards with which one has identified and set for oneself.

\subsection{The Super-Ego as Atonement Structure}

This does not, however, get to the heart of identificatory guilt in Loewald's terms. The tension between what we should like to be and what we are is one thing, and the more or less coherent, benign super-ego is the means for making that measure. More than this, the super-ego is for Loewald in its very existence an atonement structure. Loewald's deeper point here is that a sense of guilt is embedded in the very process of forming a super-ego, because doing so involves casting off those very people whom one has until that point loved and taken in in order to be oneself. This is the true aftermath of resolving the Oedipus complex. Creating a super-ego-being a self-reliant individual-requires one to do this, but it is also something that one cannot help but feel bad about. Take the father in Freud's phylogenetic story whom

\footnotetext{
21 In his New Introductory Lectures on Psychoanalysis (1933), Freud observed that his account of the super-ego seems 'to have picked out only the parents' strictness and severity..., whereas their loving care seems not to have been taken over and maintained' $(1933,62)$. Perhaps to address this, he now identifies three functions of the super-ego: self-observation, conscience and maintaining the ideal models drawn from parents, educators and teachers.
} 
the sons both love and hate. Loving and hating the father are perfectly understandable in terms of the Oedipal drama, since love reflects identification with him, while hate represents the need to break from him. Hostility to the father is part of the quest to become oneself, for it reflects the conflict in the child's 'quest for emancipation and self-responsibility with his desire for identification and becoming one with his father' (Loewald 1980, 391). One loves the father, but out of love for oneself, must also resent him - and then feel bad about it.

This is not just a matter of fathers and sons. One can speak more generally of 'the parent' here, for the same is true of any parental figure, and for the girl as well as the boy. The parent is a constitutive part of the child's psychic being, and the child has to make that psychic being its own. That means it must actively suppress the parental identification and, in so doing, must confront that part of its own being that up to that point had been constituted by the parent. The Oedipal struggle is thus to negate the parent insofar as the parent has until then been constitutive of the child's identity. The child's aim is to create a clearer, demarcated, sense of its own selfhood, developing its interiority and subjectivity by forcing the parent more completely outside, at a distance from the emerging self, so that it may be emancipated. The parent has to be sidelined, but that necessary act can hurt and disturb:

In an important sense, by evolving our own autonomy, our own superego ..., we are killing our parents. We are usurping their power, their competence, their responsibility for us, and we are abnegating them, rejecting them as libidinal objects. In short we destroy them in regard to some of their qualities hitherto most vital to us. Parents resist as well as promote such destruction no less ambivalently than children carry it out (Loewald 1980, 390).

To 'kill' one's (psychic identification with) parents in order to be oneself is necessary, but it involves rejection at the deepest, most constitutive, psychic level of a person's being. The happiness of selfhood is thus measured against remorse at the manner of its achievement, the death inside of the fused child-parent entity. This is the basis of the guilt that accompanies the creation of the super-ego, and links the super-ego thereafter to a residual need to atone:

Without the guilty deed of parricide there is no autonomous self ... no individual self worthy of that name, no advanced internal organisation of psychic life, [so that] guilt and atonement are crucial motivational elements of the self (Loewald 1980, 393).

That is why, as the quote at the beginning of this section continues, guilt is not 'a troublesome affect' to be eliminated, but 'one of the driving forces in the organisation of the self'. That is why the autonomous, responsible self 'is an atonement structure, a structure of reconciliation, and as such a supreme achievement' (Loewald 1980, 394). At the core of Freudian psychoanalysis in its later structural phase is the theory of identification between parent and child. The growth of personhood occurs through the taking in of models drawn from those who offer a loving identification for the child. From the earliest world of the unformed libidinous id, the primary narcissistic state evolves through the creation of an ego and ego ideals into the more complex 
self-organisation of the super-ego. The latter is achieved by virtue of a struggle over identification for identity, autonomy and emancipation, with the closest loving figures who have nurtured the child. This is a battle as the child resets its relationships, establishing a more coherent and sophisticated self in a way that radically alters intrapsychic and interpsychic relations. To do so is to abandon central arrangements of the child's psychic life up to that point, in exchange for a qualitative enrichment of the powers of the self. Eventually a renegotiated relationship with parents will emerge, but the struggle leaves its mark. It involves the repudiation of a debt owed, the expunging of a love given and taken, leaving the foundational imprint of the bad feeling we call guilt, and, from that, an underlying instinct to repair and atone.

\subsection{Guilt and the Undone Self}

If the Oedipal experience might engrain the psyche with guilt and the need to atone, there is a final element I should like to propose. The experience of guilt is not just related to how one treated the loved parent, it is also concerned with displacement within the child as it sets the parent at a distance. This fundamentally disturbs its own sense of self as it has existed to that point. Through identification, the parent had been a constitutive part of the child's evolving ego, so that the Oedipal struggle involves both negating the parent-in-the-child and the child's own parent-child self up to that point. This involves at the least disturbance of the existing sense of self in the time before it can be reconstituted through resetting parent-child boundaries. This suggests both a sense of feeling bad (guilty) about repudiating those one loves, and an internal sense of being psychically undone. Displacing the parents leaves the child internally stripped out, just as a new, more sophisticated, sense of self comes into being. To feeling bad for the loved other is added the bad feeling that is the turbulence brought about by displacement in one's being.

Talk of the Oedipal drama and of 'killing' the parent puts the point of rejection and negation dramatically. Of course, there may be times when the child imagines it would like to 'kill' the parent, and the metaphor makes the point that this is a profound shift in the nature of their relationship. In reality, of course, parricide is a part of a psychic, not factual reality (Loewald 1980, 393), and the result is usually not the actual death of the parent, but rather the evolution of the parent-child relationship to one where there is 'some sort of balance, equality, or transcending conciliation', albeit one that 'remains vulnerable' (Loewald 1980, 395). But the experience of love and rejection, of destabilisation and reconfiguration is formative, and it gives a psychological basis for the existence of guilt as the sense of feeling bad about another, and of feeling bad (undone) within oneself. Guilt involves both aspects, and in its formative aspect, is an existential development.

\subsection{Prospective Identification and Stranger Killing}

How could this experience of guilt and atonement be relevant beyond the Oedipal time? The argument is that this period of struggle of the self leaves the psyche with 
both the means to measure ego ideals against actual performance (responsibility) and an imprint or template in terms of guilt and the need to atone (feeling bad about another and within oneself). For Freud, the psychic stages a person passes through leave their mark. While we might think the Oedipal stage to be one that once passed is in the past, Freud insisted that past psychic experiences leave their mark. Loewald makes the point beautifully, quoting from the lines of Ariel in Shakespeare's The Tempest, with which I prefaced this essay: "nothing fades, "but doth suffer a sea-change into something rich and strange" (Loewald 1980, 394). Guilt as a bitter and disturbing moral event is painful, leaving one feeling bad-'rotten, depleted of energy, tense', as Morris puts it. If such a moral experience can be described, what are the psychic mechanisms that make it possible? From the theory of super-ego formation, we find an intrinsic sense of guilt emerging from the structural formation of the human ego. The desire to atone is written into our psychological being, while the connection to ego ideals that have not been followed provides the responsibility trigger for guilt to occur. We can be responsible for what has occurred and feel bad about it. This Loewaldian line out of Freud provides us with a way of understanding what it might mean to feel guilty.

But, of course, people may feel guilty in connection with acts they have done that are not related to close others. The question then becomes: how do we get from guilt in the resolution of personal identity with parental figures to guilt for the violation of another person who may indeed be a stranger? The guilt of parricide stems from the fact that one is killing a loved other and part of oneself. This is a very particular drama in the formation of the coherent and autonomous ego. The question is whether it has relevance for thinking not only about the guilt of the metaphoric parricide, but also, for example, for the harm in killing another human being who may be a complete stranger. Actual homicides really do happen, and we have to think about why the perpetrator might then feel bad. How could that be where the connection between the perpetrator and the victim may involve no prior identificatory relationship?

I suggest that the way to think beyond metaphoric parricide to guilt in real 'stranger homicide' is in terms of 'prospective' or 'anticipatory' identification. To kill another human being is to put an end to a figure who has been a potential object of love and identification. It is to destroy a person who would have been a source of identification for others, and who might have been a figure who the perpetrator could under other circumstances have 'taken in'. Identificatory possibilities extend broadly, indeed to all members of the human species. Every person is a potential source of identification: we are all some mother's child, some child's possible parent. ${ }^{22}$ Every human being is constituted by libidinous object love, identification and ego formation; we are all the same. To symbolically kill the Oedipal object of one's identificatory love is to repudiate in psychic reality a part of one's self. To actually

\footnotetext{
22 This is the source of the idea of a metaphysical guilt that extends universally and is picked up by world religions (Morris 1987, 240). Though I don't show it here, I suggest it lies at the root of Karl Jaspers's account of German war guilt as metaphysical (Jaspers 2000), on the importance of which see Norrie (2017a, ch. 6).
} 
kill another is to put an end to a source of identificatory love for others in a real sense. Imagined parricide of a love figure is close to home, but its benevolent upshot can be a development of a further, more balanced, relationship with the loved figure who survives. Actual homicide combines a more distant relation with another human being with a form of destruction that is real and complete. No one survives her own homicide. To kill in this way is to destroy a figure who was capable of identification, who had the possibility of loving identification of and for another, who in relevant psychic ways is just like the killer.

To illustrate the point about guilt at the killing of a stranger, just such a logic is to be found in Dostoyevsky's Crime and Punishment, where the author describes Raskolnikov's grief at killing the old woman. In this account, Raskolnikov experiences both the sense of a punishment that comes back to himself through identification with the victim, and the way in which his existential being is disturbed. With regard to the former, he asks: 'Did I really kill the old woman? No, it was myself I killed!-it was myself I have irrevocably ruined!' (Dostoyevsky 1997, 334). This is identificatory guilt with the old woman to whom emotionally he was a stranger. With regard to the latter, he 'suffered cruelly from this conviction, that everything, even memory, even the most elementary prudence, was abandoning him'. He asks: 'Can this be the punishment already beginning? Indeed, indeed, it is!' (Dostoyevsky 1997, 74). This is his own sense of being undone that partners identificatory guilt. These are the two different grounds for bad feeling that can be deduced from the account of guilt and super-ego formation around the idea of identification. They may exist in the case of the real stranger-killer just as much as in the psychic reality of metaphoric parricide. They are underpinned by an anticipatory or prospective identification. They constitute the basis for a moral grammar of guilt and reconciliation that can be identified both philosophically (Norrie 2018a) and in ethical practices of seeking and giving forgiveness (Norrie 2018b).

\section{Linking the Metapsychology and Metaphysics of Guilt}

We began this discussion with Williams and the bridgehead he offered to two critiques of guilt. The first was the political critique of guilt as a core part of the "peculiar', institutionally fused, form of morality in the modern liberal state. This suggests why the modern discourse of guilt is essentially limited. The second was the demand for a moral psychology that could deepen moral theory, and help to understand what a term such as 'guilt' might truly mean once we got beyond its modern appearance in the 'peculiar' institution. This suggests how the modern discourse of guilt is limited and may be overcome. We pursued this second line through Morris's thoughtful account of guilt, atonement and identification. Taking these together, we identified an account of guilt that went beyond moral guilt in its 'peculiar' form, to a deeper sense of the relationship between wholeness, love, atonement and identification. In Morris, these terms nonetheless lack grounding in moral psychology taken to the deepest level, that of Williams's 'psychological materials' - though there is oblique reference to psychoanalytical mechanisms around the idea of identification in his work. 
The claim to take moral psychology to its deepest level raises important questions about what we should find there. We noted that Williams was ambivalent between anger and love, though it is anger that comes to the fore in his limited sally into the 'psychological material'. This suggests a very different approach to that which comes from Morris, for there atonement is related to wholeness and love, and identification is related to fellowship with another into whose being one enters. Anger could not be the first port of call for Morris. The anger the guilty person feels must be for a failing in relation to love, wholeness and the other with whom one identifies, not just because of an internalised, redirected anger. Yet, here we confronted a possible impasse, in that Freud's metapsychology of guilt clearly focuses on aggression, fear and anger, and not on love. We noted, however, that such an approach was not inevitable if we pursued Freud's thought, picking up Lear's point that there was an unreconciled conflict in Freud between the earlier pleasure-based theory and the later structural account based on love's 'enforming'. The latter leads psychoanalysis down the route to happiness, and thereby aligns it with the Aristotelian approach in ethics to truth, eudaimonia, self-knowledge and the relationship between the rational and the non-rational self. Lear's remarkable contribution is to show how Freud follows in this line and produces in his metapsychology a potentially richer answer to the ancient questions. ${ }^{23}$ Williams perhaps sensed this possibility in some of his broader statements about Freud and moral psychology, but his 'psychological materials' in Shame and Necessity did not move in such a direction.

Finally, we reached beyond Lear to his mentor in metapsychology, Loewald, whose account of responsibility and the super-ego as an atonement structure provides both an immediate link to Morris's account, and locates the feeling of guilt in formation of the human psyche. Guilt most fundamentally relates to the creation of a self organised around ego ideals and a super-ego. It is concerned with how a person handles identification with parental figures (the creation of ego ideals), and especially ambivalence to those one loves and holds onto, and must discard in order to be oneself (the creation of the super-ego as an atonement structure). Feeling bad is written into the human script, and remains a residual ethical reflex for post-Oedipal encounters. Just as parents enter into the developing child's psyche, and that psyche experiences guilt at discarding an identification at its heart, so the post-Oedipal child and adult enters into loving relations with others through a variety of relationships. The unity these bring, if broken, triggers a desire to atone embedded in the enformed psyche. Such unity may be with those who are strangers to us, so that identification for guilt may be anticipatory or prospective, based on universal feelings of solidarity.

This point about strangers links Loewald's metapsychological argument with Morris's metaphysical one. The unity that comes from 'entering into' the life of the other qua stranger lies in the experience of prospective identification, by means

\footnotetext{
23 Aristotle's answer to the question of knowledge of the non-rational self is limited (see Lear 2015, 26-27, notes 14 and 23), and accordingly, since the person cannot properly unify herself, one could think this explains why Aristotle's account of the development of the virtues rests on the importance of education and training rather than their reflective adoption by a person.
} 
of which a broad, even universal, form of identification with other members of the human species is possible. We can tie the psychological argument for prospective identification together with Morris's account of (wrongly named) 'nonmoral' guilt, for he too argues for just such a universal form of guilt:

Now, if we accept the legitimacy of identificatory ties ... can we not also find it acceptable that individuals establish those identificatory ties with others and that they may do this without irrationality? We might not ourselves make such commitments; but others reveal through their emotional responses that they have. Some even reveal, as much religious thought makes evident, a scope of identification that embraces the human race. I do not myself presently see that such a position is open to challenge (Morris 1987, 240).

What is needed for an adequate moral psychology is that we can relate Morris's moral intuition to an adequate account of psychic development-ground it in the 'psychological material'. There is a route to do this through Freud, Lear and Loewald. Through them, we can see how prospective identification becomes the possible basis for an ethical guilt and atonement located in human moral psychology: how metapsychology grounds metaphysics without reducing the one to the other. In this way, we reinvigorate the Aristotelian impulse to consider happiness as eudaimonia by interpreting what we might call the 'rational' (the moral) and the 'non-rational' (the nonmoral) sides of guilt. We thereby expand the bounds of ethical philosophy as we pursue the ancient philosophical injunction to know ourselves-in modern, Freudian, terms as animals who think and love.

Acknowledgements I thank Henrique Carvalho, Antony Duff, Peter Ramsay and Craig Reeves for their comments.

Funding The essay was written while the author was a Major Research Fellow supported by the Leverhulme Trust (Grant No. MRF-2014-122).

Open Access This article is distributed under the terms of the Creative Commons Attribution 4.0 International License (http://creativecommons.org/licenses/by/4.0/), which permits unrestricted use, distribution, and reproduction in any medium, provided you give appropriate credit to the original author(s) and the source, provide a link to the Creative Commons license, and indicate if changes were made.

\section{References}

Altham, JEJ and R Harrison (1995) World, Mind and Ethics. Cambridge: Cambridge University Press. Aristotle (1984) Nicomachean Ethics. Complete Works, Volume 2. Princeton: Princeton University Press. Carvalho, H (2017) The Preventive Turn in Criminal Law. Oxford: Oxford University Press.

Deigh, J (1996) 'Remarks on Some Difficulties in Freud's Theory of Moral Development' in The Sources of Moral Agency. Cambridge: Cambridge University Press.

Dostoyevsky, F (1997) Crime and Punishment. London: Penguin.

Farmer, L (2016) Making the Modern Criminal Law. Oxford: Oxford University Press.

Freud, S (1933) New Introductory Lectures on Psychoanalysis. In J. Strachey, Standard Edition of Complete Works of Sigmund Freud (1964). Volume XXII

Freud, S (1984) On Metapsychology: The Theory of Psychoanalysis. Penguin Freud Library, Volume 11. London: Penguin. 
Freud, S (1985) Civilization, Society and Religion. Penguin Freud Library, Volume 12. London: Penguin. Freud, S (1990) The Origins of Religion. Penguin Freud Library, Volume 13. London: Penguin.

Jaspers, K (2000) The Question of German Guilt. New York: Fordham University Press. Lacey, N (2016) In Search of Criminal Responsibility. Oxford: Oxford University Press.

Lear, J (1988) Aristotle: The Desire to Understand. Cambridge: Cambridge University Press.

Lear, J (1990) Love and Its Place in Nature: A Philosophical Interpretation of Freudian Psychoanalysis. New Haven: Yale University Press.

Lear, J (1998) Open Minded. Cambridge: Harvard University Press.

Lear, J (2003) 'The Idea of a Moral Psychology: The Impact of Psychoanalysis on Philosophy in Britain' International Journal of Psychoanalysis 84(5): 1351-1361.

Lear, J (2004) 'Psychoanalysis and the Idea of a Moral Psychology: Memorial to Bernard Williams' Philosophy' Inquiry: An Interdisciplinary Journal of Philosophy 47(5): 515-522.

Lear, J (2015) Freud (2nd ed). Abingdon: Routledge.

Lear, J (2017) Wisdom Won from Illness. Cambridge: Harvard University Press.

Loewald, H (1980) Papers on Psychoanalysis. New Haven: Yale University Press.

Mitchell, S (1998) 'From Ghosts to Ancestors: the Psychoanalytic Vision of Hans Loewald' Psychoanalytic Dialogues 8(6): 825-855.

Mitchell, S and M Black (1995) Freud and Beyond. New York: Basic Books.

Morris, H (1976) On Guilt and Innocence: Essays in Legal Philosophy and Moral Psychology. Berkeley: University of California Press.

Morris, H (1987) 'Nonmoral Guilt' in Responsibility, Character and the Emotions, edited by F. Schoeman. Cambridge: Cambridge University Press.

Murphy, J (2012) Punishment and the Moral Emotions. Oxford: Oxford University Press.

Norrie, A (1991) Law, Ideology and Punishment. Dordrecht: Kluwer.

Norrie, A (2000) Punishment, Responsibility and Justice. Oxford: Oxford University Press.

Norrie, A (2014) Crime, Reason and History (3rd ed). Cambridge: Cambridge University Press.

Norrie, A (2017a) Justice and the Slaughter Bench. Abingdon: Routledge.

Norrie, A (2017b) 'Criminal Law and Ethics: Beyond Normative Assertion and Its Critique' Modern Law Review 80(5): 955-973.

Norrie, A (2018a) 'Love in Law's Shadow: Political Theory, Moral Psychology and Young Hegel's Critique of Punishment' Social and Legal Studies. https://doi.org/10.1177/0964663918758512.

Norrie, A (2018b) 'Love Actually: Law and the Moral Psychology of Forgiveness' Journal of Critical Realism. https://doi.org/10.1080/14767430.2018.1472409.

Ramsay, P (2009) The Insecurity State. Oxford: Oxford University Press.

Williams, B (1993) Shame and Necessity. Berkeley: University of California Press.

Williams, B (1995) Making Sense of Humanity. Cambridge: Cambridge University Press.

Williams, B (2011) Ethics and the Limits of Philosophy. Abingdon: Routledge. 